Trauma Berufskrankh 2008 10 [Suppl 3]:381-383

DOI 10.1007/s10039-008-1351-7

Online publiziert: 27. März 2008

(c) Springer Medizin Verlag 2008
A. Jester - A. Harth - G. Germann

Klinik für Hand-, Plastische und Rekonstruktive Chirurgie Schwerbrandverletztenzentrum, BG-Unfallklinik Ludwigshafen, Hand- und Plastische Chirurgie der Universität Heidelberg, Ludwigshafen

\section{„Disability of Arm, Shoulder and Hand"'-Fragebogen}

\section{Bisherige Erfahrungen}

Funktionelle Einschränkungen an der oberen Extremität durch Erkrankungen oder Verletzungen haben eine erhebliche sozioökonomische Bedeutung [4]. Somit erstaunt es nicht, dass in den letzen 20 Jahren eine Vielzahl an Tests zur Qualitätskontrolle und Messung von Behandlungsergebnissen bzw. der Erfassung eines Krankheitsstatus entwickelt wurde, welche die Einschränkungen vor und nach der Therapie erfassen sollten $[1,3,4,5,6$, $12,17,18,19,23]$.

Der „Disabilities of Arms, Shoulder and Hand Questionnaire" (DASH) hat sich mittlerweile weltweit als am häufigsten eingesetzter Fragebogen bei der Evaluation des funktionellen Zustands bei Erkrankungen und Verletzungen der oberen Extremität erwiesen. So ist er bereits in 14 verschiedenen Ländern validiert $[2,7,8$, $9,11,12,13,15,16,21,22,24,25]$ und wird weltweit routinemäßig eingesetzt. Nachfolgend werden die Forschungsergebnisse, die bei seinem Einsatz gewonnen werden konnten, erläutert.

\section{Übersetzung des DASH ins Deutsche}

Der DASH wurde 1994 von der amerikanischen „Upper Extremity Collaborative Group “ für die Erfassung von Einschränkungen an der gesamten oberen Extremität entwickelt. Es handelt sich um einen Self-Report-Fragebogen, dies bedeutet, dass er die subjektive Wahrnehmung des Betroffenen im Bezug auf seinen derzeitigen Zustand erfasst. Enthalten sind Fragen zu den Bereichen:
- Körperfunktion und -strukturen

- berufliche und allgemeine Aktivitäten

- soziales Leben

Durch Germann et al. [9] erfolgte die Übersetzung nach den von Guillemin et al. [10] vorgeschlagenen Richtlinien überkultureller Übersetzung. Der dafür erforderliche Prozess setzt eine systematische Vorgehensweise voraus, da eine bloße sprachliche Übersetzung der interkulturellen Adaptation nicht gerecht werden kann. Bei der Übersetzung eines solchen subjektiven Erfassungsbogens müssen vielmehr auch landestypische Besonderheiten mit erfasst und entsprechend eingearbeitet werden.

\section{Validierung des DASH}

Die Validierungsstudie wurde an $342 \mathrm{~Pa}-$ tienten, 98 Frauen und 244 Männern, durchgeführt. Hierbei handelte es sich um primär an der Klinik für Rekonstruktive, Plastische und Handchirurgie der BG-Unfallklinik Ludwigshafen behandelte Patienten in den Jahren von 1997-1999 mit den in $\bullet$ Tab. 1 aufgeführten Diagnosen. Die Stichprobenverteilung von $25,1 \%$
Frauen und 74,9\% Männern entspricht in etwa der in dieser Klinik üblichen geschlechtsspezifischen Verteilung.

Befragt wurden Patienten, die folgende Voraussetzungen erfüllten:

- hinreichende Kenntnisse in der deutschen Sprache

- Alter über 18 Jahre

Alle Patienten beantworteten den DASH nur einmal zum Abschluss ihrer Behandlung.

Um die kriterienbezogene Validität zu überprüfen, wurde bei 183 Patienten (• Tab. 2) zusätzlich der Disability-Index nach Dillmann (DI) [20] appliziert, wobei die Auswahl der Diagnosegruppen zufällig erfolgte. Dieser Fragebogen wurde zur Validitätsüberprüfung nur bei diesen Patientengut erhoben und kam später nicht mehr zur Anwendung. Ursprünglich wurde er zur Schmerzerfassung benutzt. Er erfasst die subjektive Einschätzung des Patienten bezüglich seines derzeitigen Behinderungsgrads in 7 verschiedenen Lebensbereichen:

- familiäre und häusliche Verpflichtungen,

- Erholung,

\title{
Tab. 1 Patientengruppen
}

\begin{tabular}{llll}
\hline Diagnosegruppen & Anzahl gesamt & Männer & Frauen \\
Strahlamputationen & 77 & 64 & 13 \\
\hline Verbrannte Hände & 31 & 24 & 7 \\
\hline Läsion des N. medianus & 18 & 14 & 4 \\
\hline Verletzung der Kapselmittelgelenke & 66 & 43 & 23 \\
\hline Handgelenkarthrodesen & 110 & 88 & 22 \\
\hline Resektionssuspensionsarthroplastiken & 40 & 11 & 29 \\
\hline
\end{tabular}


Trauma Berufskrankh 2008 10

[Suppl 3]:381-383

DOI 10.1007/s10039-008-1351-7

(C) Springer Medizin Verlag 2008

A. Jester · A. Harth · G. Germann „Disability of Arm, Shoulder
and Hand"-Fragebogen.
Bisherige Erfahrungen

\section{Zusammenfassung}

Der "Disability of Arm, Shoulder and Hand"Fragebogen (DASH) hat sich mittlerweile weltweit als Self-Report-Fragebogen zur Beurteilung des funktionalen Zustands nach Verletzungen oder Erkrankungen der oberen Extremität durchgesetzt. Nachdem er im deutschsprachigen Raum zunächst nach den von Guillemin vorgeschlagenen Richtlinien übersetzt worden war, folgte seine Validierung. Nachfolgend wurde diese Version als offiziell zertifizierte deutsche Version akkreditiert. Es folgten Untersuchungen zur Möglichkeit der Darstellung diagnosespezifischer Profile, die Erhebung von Referenzwerten und Untersuchungen bezüglich statistischer Möglichkeiten der Vergleichbarkeit von DASH-Daten. Insgesamt hat sich der DA$\mathrm{SH}$ als effizientes und wertvolles Instrument bei der Evaluation funktioneller Ausfälle der Befragten erwiesen.

\section{Schlüsselwörter}

Obere Extremität · DASH · Validierung ·

Referenzwerte · T-Normierung

\section{Disability of Arm, Shoulder and Hand Questionnaire. Experience to date}

\begin{abstract}
The Disability of Arm, Shoulder and Hand Questionnaire (DASH) has been accepted worldwide as a self-report questionnaire designed to assess the functional status of the upper extremity following injury or disease. Following its initial translation for Germanspeaking countries according to the guidelines proposed by Guillemin, DASH received its validation. This version was subsequently accredited as the officially certified German version. Research was then carried out to investigate the possibility of developing diagnosis-specific profiles, as well as establishing reference values and examinations in order to statistically compare DASH data. Altogether, DASH has proved to be an effective and valuable tool for the evaluation of functional loss among respondents.
\end{abstract}

\section{Keywords}

Upper extremity · DASH · Validation Reference values $\cdot \mathrm{T}$-standarization
Tab. 2 Zusätzlich mit Disability-Index nach Dillmann geprüfte Patienten

\begin{tabular}{ll}
\hline Diagnosegruppe & Anzahl \\
Strahlamputation & 77 \\
\hline $\begin{array}{l}\text { Verletzungen der Mittelgelenke } \\
\text { Resektionssuspensions- } \\
\text { arthroplastik }\end{array}$ & 66 \\
\hline Insgesamt & 183 \\
\hline
\end{tabular}

- soziale Aktivitäten,

- Beruf,

- Sexualleben,

- Selbstversorgung und

- lebensnotwenige Tätigkeiten.

Auf einer Skala, die sich zwischen o (keine Behinderung) und 10 (völlige Behinderung) aufspreizt, gibt der Patient das Ausmaß seiner Beeinträchtigung an. Durch Aufsummierung der Items wird ein Wert zwischen o und 70 als Gesamtmaß für die Behinderungseinschätzung erhalten.

Der DI wurde aus dem Original in die deutsche Sprache übersetzt [20]. Er ist ausreichend validiert und erfüllt die „Review Criteria of Scientific Review Committee of the Medical Outcomes Trust“. Hauptsächlich wird er bei schmerzbedingten Behinderungen eingesetzt, aber auch zur Erfassung des Behinderungsgrads bei Diabetespatienten erfolgreich appliziert. Die deutschen Autoren waren der Meinung, dass er auch als ein Instrument zur Erfassung einer Handproblematik geeignet ist (Nilges, persönliche Mitteilung). Da es ansonsten zum Untersuchungszeitpunkt im deutschsprachigen Raum keinen anerkannten validierten Selbsterfassungsbogen gab, wurde der er zur Validitätsüberprüfung verwendet.

Zur Überprüfung der kriterienbezogenen Validität wurde die Korrelation der Einzelmodule sowie des DASH-Gesamtwerts zum Disability-Index nach Dillmann überprüft. Vorher wurde die Korrelation der Einzelmodule Funktion, Symptom und Sport untereinander und zum Gesamt-DASH geprüft. Bei der Überprüfung zeigten sich hohe Korrelationen zwischen DASH und Disability-Index.

Nach der Validierung erfolgte die Zertifizierung des deutschsprachigen DASH als offizielle deutsche Version.

\section{Überprüfung diagnose- spezifischer Aktivitätsprofile}

Da die Fragen im DASH teilweise sehr spezifisch sind, wurde bereits frühzeitig nach der initialen Anwendung postuliert, dass er diagnosespezifische Unterschiede bei spezifischen Krankheiten bzw. Verletzungen abbilden könnte. Dies wurde sowohl hinsichtlich des Gesamtscores als auch hinsichtlich der Einzelfragen überprüft. Dazu wurden in den Jahren von 1998-2000 13 Nachuntersuchungen durchgeführt, bei denen der DASH verwendet wurde.

13 diagnostische Subgruppen wurden in ihren DASH-Items und Funktionsbereichen hinsichtlich Auffälligkeiten untersucht. Das Ziel der vorangestellten rein explorativen Berechnungen war die Beantwortung der Frage, ob sich innerhalb eines Gesamtdatenpools an DASH-Daten diagnostische Subgruppen identifizieren lassen und mit welchen Indikatoren dies möglich ist. Eine Auffälligkeit wurde im Sinne einer Abweichung vom Gesamtdatenpool definiert. So konnte überprüft werden, ob sich die Kategorisierung nach diagnostischen Entitäten auch statistisch in den DASH-Ergebnissen abbildet.

Die Berechnungen erfolgten anhand einer Poweranalyse auf der Basis eines 2Stichproben-Tests (Mann-Whitney-UTest). Bei diesem Schritt ist ausdrücklich auf den rein explorativen, d. h. Hypothesen generierenden Charakter hinzuweisen. Weitere statistische Untersuchungen konnten für diese Ergebnisse nur partiell wiedergegeben werden.

\section{Erhebung von Referenzwerten}

Der klinische Einsatz des DASH macht die Notwendigkeit eines Bezugsrahmens für klinische Daten deutlich. Die Verfügbarkeit von Referenzdaten einer nicht erkrankten Personengruppe eröffnet methodisch, diagnostisch und auch therapeutisch verbesserte Anwendungsmöglichkeiten für klinische Belange.

Im Rahmen einer Studie wurden nichtklinische Referenzdaten an einer großen Stichprobe erhoben. Hierdurch wurde es möglich, die Besonderheiten eines nichtklinischen Kollektivs zu evaluieren und (Vergleichs-)Daten auch für künftige Stu- 
dien zu gewinnen. Die Durchführung und die Ergebnisse sind publiziert [14].

\section{Vergleichbarkeit von DASH-Daten}

Aufgrund von Unterschieden in der Standardabweichung können DASH-Daten lediglich innerhalb einer untersuchten Datengruppe miteinander verglichen werden. Vergleiche zwischen verschiedenen Diagnosegruppen, verschiedener Kliniken oder international sind nicht ohne weiteres möglich. Hier ist eine Umwandlung in T-Werte notwendig. Dies geschieht zur:

- Maßstabsangleichung

- Individuellen Positionsbestimmung innerhalb einer definierten Personengruppe

- Vergleichbarkeit von Individuen verschiedener Personengruppen

- Erreichung einer Individuen- und Gruppenpositionierung innerhalb zusammengelegter Datenverteilungen

Das genaue statistische Vorgehen und die Untersuchungsgruppen werden an anderer Stelle publiziert.

\section{Schlussfolgerung}

Letztendlich hat sich der DASH nicht nur in unserer Forschungsgruppe, sondern weltweit als wertvolles Instrument bei der Evaluation funktioneller Einschränkungen an der oberen Extremität erwiesen. Er kann hierbei nicht nur als Zahlenwert beim Ausrechnen des Endwerts herangezogen werden, sondern liefert bei Betrachtung der Einzelitems wichtige Hinweise über Einschränkungen und Probleme der Patienten.

\section{Korrespondenzadresse}

\section{A. Jester}

Klinik für Hand-, Plastische und Rekonstruktive Chirurgie Schwerbrandverletztenzentrum, BG-Unfallklinik Ludwigshafen, Hand- und Plastische Chirurgie der Universität Heidelberg, Ludwig-Guttmann-Straße 11, 67071 Ludwigshafen andrea.jester@urz.uni-heidelberg.de

Interessenkonflikt. Der korrespondierende Autor weist auf folgende Beziehung/en hin: Teile von DASHStudien wurden durch den HVGB unterstützt

\section{Literatur}

1. Amadio P (1997) Outcomes assessment in hand surgery. What's new? Clin Plast Surg 24: 191-194

2. Atroshi I, Gummesson C, Andersson B et al. (2000) The disabilities of the arm, shoulder and hand (DA$\mathrm{SH})$ outcome questionnaire: reliability and validity of the Swedish version evaluated in 176 patients. Acta Orthop Scand 71: 613-618

3. Bullinger M (1995) German translation and psychometric testing of the SF-36 health survey: preliminary results from the IQOLA project. International quality of life assessment. Soc Sci Med 41: 1359-1366

4. Chung K, Pillsbury M, Walters M et al. (1998) Reliability and validity testing of the Michigan hand outcomes questionnaire. J Hand Surg [Am] 23: 575-587

5. Cooney W, Bussey R, Dobyns J et al. (1987) Difficult wrist fractures: perilunate fracture - dislocations of the wrist. Clin Orthop 214: 136-147

6. Dias J, Bhowal B, Wildin C et al. (2001) Assessing the outcome of disorders of the hand. Is the patient evaluation measure reliable, valid, responsive and without bias? J Bone Joint Surg Br 83: 235240

7. Durand M, Vachon B, Hong Q et al. (2005) The cross-cultural adaptation of the DASH questionnaire in Canadian French. J Hand Ther 18: 34-39

8. Fayad F, Lefevre-Colau M, Mace Y et al. (2007) Validation of the French version of the disability of the arm, shoulder and hand questionnaire (F-DASH). Joint Bone Spine Aug 30; [Epub ahead of print]

9. Germann G, Harth A, Wind G et al. (2003) [Standardisation and validation of the German version 2.0 of the disability of arm, shoulder,hand (DASH) questionnaire]. Unfallchirurg 106: 13-19

10. Guillemin F, Bombardier C, Beaton D (1993) Crosscultural adaptation of health-related quality of life measures: literature review and proposed guidelines. J Clin Epidemiol 46: 1417-1432

11. Hervas M, Navarro Collado M, Peiro S et al. (2006) [Spanish version of the DASH questionnaire. Crosscultural adaptation, reliability, validity and responsiveness]. Med Clin (Barc) 127: 441-447

12. Hudak PI, Amadio P, Bombardier C (1996) Development of an upper extremity outcome measure: the DASH (disabilities of the arm, shoulder and hand) [corrected]. The Upper Extremity Collaborative Group (UECG). Am J Ind Med 29: 602-608

13. Imaeda T, Toh S, Wada T et al. (2006) Validation of the Japanese Society for Surgery of the Hand version of the quick disability of the arm, shoulder, and hand (QuickDASH-JSSH) questionnaire. J Orthop Sci 11: 248-253

14. Jester A, Hart A, Germann G (2005) Measuring levels of upper-extremity disability in employed adults using the DASH questionnaire. J Hand Surg [Am] 30: 1074.e1-1074.e10

15. Lee E, Lau J, Chung M et al. (2004) Evaluation of the Chinese version of the disability of the arm, shoulder and hand (DASH-HKPWH): cross-cultural adaptation process, internal consistency and reliability study. J Hand Ther 17: 417-423

16. Liang $\mathrm{H}$, Wang $\mathrm{H}$, Yao $\mathrm{G}$ et al. (2004) Psychometric evaluation of the Taiwan version of the disability of the arm, shoulder, and hand (DASH) questionnaire. J Formos Med Assoc 103: 773-779

17. Macdermid J, Turgeon T, Richards R et al. (1998) Patient rating of wrist pain and disability: a reliable and valid measurement tool. J Orthop Trauma 12: 577-586
18. Martin D, Engelberg R, Agel J et al. (1996) Development of a musculoskeletal extremity health status instrument: the musculoskeletal function assessment instrument. J Orthop Res 14: 173-181

19. Martini A (1999) Bewertungsschemata zur Beurteilung des Handgelenkes. Handchir Mikrochir Plast Chir 31: 153-154

20. Nilges P, Gerbershagen H, Dillmann U et al. (1994) Schmerzbedingte Behinderung: eine deutsche Version des „Pain Disability Index“. Schmerz 8: 41

21. Orfale A, Araujo P, Ferraz M et al. (2005) Translation into Brazilian Portuguese, cultural adaptation and evaluation of the reliability of the disabilities of the arm, shoulder and hand questionnaire. Braz J Med Biol Res 38: 293-302

22. Padua R, Padua L, Ceccarelli E et al. (2003) Italian version of the disability of the arm, shoulder and hand (DASH) questionnaire. Cross-cultural adaptation and validation. J Hand Surg [Br] 28: 179-186

23. Rudolf K, Preisser P, Partecke B (1999) Vergleich verschiedener Bewertungsmaßstäbe zu Beurteilung des Behandlungserfolges nach Kahnbeinfrakturen. Handchir Mikrochir Plast Chir 31: 155-161

24. Themistocleous G, Goudelis G, Kyrou I et al. (2006) Translation into Greek, cross-cultural adaptation and validation of the disabilities of the arm, shoulder, and hand questionnaire (DASH). J Hand Ther 19: 350-357

25. Veehof M, Sleegers E, Van Veldhoven N et al. (2002) Psychometric qualities of the Dutch language version of the disabilities of the arm, shoulder, and hand questionnaire (DASH-DLV). J Hand Ther 15: 347-354 